\title{
Limbah Baglog Jamur Tiram Putih sebagai Kompos pada Cabai Rawit (Capsicum frutescens L.) Var. Hiyung
}

\author{
White Oyster Mushroom Baglog Waste as Compost for Cayenne Pepper (Capsicum frutescens L.) \\ Var. Hiyung
}

\section{Nur H.D. Ayu, Jumar, Noorkomala Sari*}

\author{
Jurusan Agroekoteknologi, Fakultas Pertanian, Universitas Lambung Mangkurat, Jalan A. Yani Km. 36, \\ Banjarbaru 70714, Indonesia \\ *E-mail Penulis Korespondensi: noorkomala.sari@ulm.ac.id
}

\begin{abstract}
Chili pepper is a plant that is favored by the community because its fruit has a spicy taste, so it is widely cultivated by farmers. One of the chili pepper varieties in Indonesia is Hiyung cayenne pepper which originally comes from Hiyung Village of Tapin Tengah District, Tapin Regency, South Kalimantan. In plant-cultivation, fertilization has an important role to meet the nutrient needs of plants. Fertilization to reduce environmental pollution can be done by using organic fertilizers, for example by giving compost of white oyster mushroom planting media waste (baglog). The purpose of this study was to know the effect and the best dose of application of white oyster mushroom baglog waste compost on the growth of cayenne pepper (Capsicum frutescens L.) variety Hiyung. The research was carried out in February-May 2020, at the Hortibun Agroecotechnology Experimental Field, Faculty of Agriculture, Lambung Mangkurat University. The method used in this study was a Completely Randomized Design (CRD) with one factor. The treatments tested consisted of: $k 0=$ control (without baglog waste compost) or 0 tons/ha; $k 1=5$ tons/ha of baglog waste compost or $125 \mathrm{~g} /$ planting hole; $k 2=10$ tons/ha of mushroom baglog waste compost or $250 \mathrm{~g} /$ planting hole, $k 3=15$ tons/ha of mushroom baglog waste compost or $375 \mathrm{~g} /$ planting hole; and $\mathrm{k} 4=20$ tons/ha of baglog compost waste or $500 \mathrm{~g} / \mathrm{planting}$ hole. The treatment was repeated 4 times so that there were 20 experimental units. The results on the parameters of plant height, number of leaves, and productive branches showed that the application of white oyster mushroom baglog waste compost had an effect on the growth of cayenne pepper variety Hiyung. The best treatment recommendation was the K3 treatment (15 tons/ha or 375 $\mathrm{g} /$ planting hole) which was able to increase plant height by 55.9\%; number of leaves $88.2 \%$; and $160 \%$ productive branch compared to control at 42 days after planting.
\end{abstract}

Keywords: Hiyung cayenne chilli, baglog waste compost, organic fertilizer, vegetative stage

\section{ABSTRAK}

Cabai merupakan tanaman yang disukai masyarakat karena buahnya memiliki cita rasa pedas, sehingga banyak dibudidayakan oleh pada petani. Salah satu varietas cabai yang ada di Indonesia, yaitu cabai rawit Hiyung, berasal dari Desa Kecamatan Tapin Tengah, Kabupaten Tapin, Kalimantan Selatan. Dalam kegiatan budidaya tanaman, pemupukan memiliki peran yang penting untuk memenuhi kebutuhan unsur hara bagi tanaman. Pemupukan dengan tujuan mengurangi pencemaran lingkungan dapat dilakukan dengan pengunaan pupuk organik, misalnya pemberian kompos limbah media tanam jamur tiram putih (baglog). Tujuan penelitian adalah mengetahui pengaruh dan dosis terbaik aplikasi kompos limbah baglog jamur tiram putih pada pertumbuhan cabai rawit (Capsicum frutescens L) varietas Hiyung. Pelaksanaan penelitian pada Februari 2020-Mei 2020, di Kebun Percobaan Hortibun Agroekoteknologi Fakultas Pertanian Universitas Lambung Mangkurat. Metode yang digunakan dalam penelitian ini adalah Rancangan Acak Lengkap (RAL) satu faktor. Perlakuan yang diuji terdiri dari: K0 = kontrol (tanpa kompos limbah baglog ) atau 0 ton/ha; K1 = 5 ton/ha kompos limbah baglog atau $125 \mathrm{~g} /$ lubang tanam; K2 = 10 ton/ha kompos limbah baglog atau $250 \mathrm{~g} / \mathrm{lubang}, \mathrm{K} 3=15 \mathrm{ton} / \mathrm{ha}$ kompos limbah baglog atau $375 \mathrm{~g} / \mathrm{lubang}$ tanam dan $\mathrm{K} 4=20$ ton/ha kompos limbah baglog atau $500 \mathrm{~g} /$ lubang tanam. Perlakuan diulang 4 kali sehingga terdapat 20 satuan percobaan. Hasil pada parameter tinggi tanaman, jumlah daun, dan cabang produktif menunjukan bahwa aplikasi kompos limbah baglog jamur tiram putih berpengaruh pada pertumbuhan cabai rawit varietas Hiyung. Rekomendasi perlakuan terbaik terdapat pada perlakuan K3 (15 ton/ha atau 375 g/lubang tanam) yang mampu meningkatkan tinggi tanaman 55,9\%; jumlah daun 88,2\%; dan cabang produktif $160 \%$ dibandingkan dengan kontrol pada 42 Hari Setelah Tanam (HST).

Kata kunci: Cabai rawit Hiyung, kompos limbah baglog, pupuk organik

\section{PENDAHULUAN}

Tanaman cabai termasuk tanaman hortikultura yang memiliki rasa pedas dan sangat disukai masyarakat Indonesia; oleh karena itu, tanaman ini banyak dibudidayakan oleh para petani. Menurut Koassi et al. (2012), selain 
sebagai bumbu untuk hidangan, kebutuhan cabai rawit meningkat karena capsaicin dari cabai diperlukan sebagai bahan baku dalam produksi obat dan kosmetik.

Salah satu varietas cabai adalah cabai rawit Hiyung, yang berasal dari Provinsi Kalimantan Selatan, tepatnya dari Desa Hiyung, Kabupaten Tapin. Kelebihan cabai varietas Hiyung adalah memiliki tingkat kepedasan 17 kali lebih pedas dibandingkan rata-rata cabai biasa. Dari penelitian laboratorium Bogor, Jawa Barat, cabai Hiyung juga memiliki kanjdungan protein yang tinggi (5,83\%), vitamin C (763,52 ppm), dan vitamin A (11.836,42 IU/100 g). Selain itu, cabai Hiyung tidak mudah busuk (Hamdani et al., 2016).

Dalam kegiatan budidaya tanaman, pemupukan memiliki peran yang penting terutama untuk budidaya tanaman hortikultura yang memerlukan kandungan unsur hara tinggi untuk kebutuhan hidupnya. Namun menurut Fadillah et al. (2019), petani di Desa Hiyung rata-rata menggunakan pupuk anorganik untuk lahan 0,1-<0,5 ha, yaitu urea $33,5 \mathrm{~kg}$, NPK $185 \mathrm{~kg}$ dan TSP 66,8 kg. Pengunaan pupuk anorganik oleh petani secara terus menerus akan mengakibatkan pencemaran lingkungan. Menurut Purnomo et al. (2013) pupuk anorganik memiliki beberapa kekurangan, di antaranya harga yang mahal, membuat kerusakan fisik dan biologi tanah, dan jika digunakan berlebihan akan menyebabkan pencemaran lingkungan, seperti pencemaran air tanah. Dengan mengurangi penggunaan pupuk anorganik maka akan mengurangi dampak yang diakibatkan oleh pupuk anorganik tersebut.

Selanjutnya salah satu ragam pupuk organik berupa kompos bersumber dari limbah pertanian yang dapat dimanfaatkan kembali, yaitu limbah baglog yang merupakan media bekas budidaya jamur tiram putih. Limbah baglog umumnya tidak dimanfaatkan kembali dan hanya dibuang atau bahkan seringkali dibakar, yang mengakibatkan pencemaran lingkungan maupun polusi udara akibat pembakaran. Dengan pemanfaatan limbah baglog ini maka akan mengurangi pencemaran lingkungan serta mengurai limbah baglog jamur tiram yang biasanya tidak dimanfaatkan.

Menurut Sulaeman (2011), kandungan nutrisi yang terkandung dalam limbah baglog meliputi K 0,02\%, P 0,7\%, C-organik $49,0 \%$ dan $\mathrm{N}$ total $0,6 \%$, yang bermanfaat bagi tanah. Karena banyaknya bahan organik yang terkandung di dalamnya, maka limbah ini berpotensi sebagai kompos untuk budidaya cabai Hiyung. Roesmarkam dan Yuwono (2002) menyebutkan agar pertumbuhan tanaman menjadi optimal pada fase vegetatif, aplikasi pemupukan $\mathrm{N}$ lazimnya mesti seimbang dengan pemupukan unsur hara lain. Menurut Rizki et al. (2015), di dalam tanah kandungan hara $\mathrm{N}$ akan diserap secara maksimal di fase vegetatif, kemudian unsur hara yang dibutuhkan tanaman akan tercukupi. Unsur hara $\mathrm{K}$ berfungsi mengokohkan vigor tanaman, yang akan mempengaruhi lebar serta besarnya diameter lingkaran batang. Unsur hara $\mathrm{P}$ bermanfaat untuk mempercepat pembelahan dan perkembangan sel.

Diharapkan dari pemberian kompos limbah baglog jamur tiram putih pada fase vegetatif, tanaman cabai rawit varietas Hiyung mampu memenuhi kebutuhan hara pada tanaman. Selain itu, dengan pemberian kompos limbah baglog pada budidaya cabai juga dapat memanfaatkan limbah yang kurang dimanfaatkan masyarakat, serta dapat menjadi referensi baru tentang pupuk organik.

\section{BAHAN DAN METODE}

\section{Waktu dan Tempat}

Penelitian dilaksanakan dari Februari hingga Mei 2020, di Kebun Percobaan Fakultas Pertanian, Universitas Lambung Mangkurat, Banjarbaru.

\section{Alat dan Bahan}

Alat-alat yang digunakan terdiri dari cangkul, terpal, polybag semai, karung, timbangan, selang air, meteran, alat tulis dan kamera handphone.

Bahan yang digunakan meliputi benih cabai rawit Hiyung, limbah baglog jamur tiram putih, kotoran sapi, dedak padi, dekomposer M-21, gula, air, pupuk NPK.

\section{Pembuatan Kompos}

Kompos limbah baglog yang diperoleh dari tempat budidaya jamur di Martapura, Kalimantan Selatan, dipisahkan dari plastiknya. Silanjutnya disiapkan lahan kosong yang rata dan yang tidak tergenang air, dan $100 \mathrm{~kg}$ limbah baglog, $4 \mathrm{~kg}$ dedak padi serta $40 \mathrm{~kg}$ kotoran sapi dicampurkan. Sebanyak $100 \mathrm{~g}$ gula dan $140 \mathrm{~mL} \mathrm{M-21}$ dilarutkan dalam air lalu diaduk sampai rata. Setelah itu, larutan decomposer itu disiramkan sampai kadar air sekitar $30 \%$, yang cirinya jika bahan digenggam air tidak menetes. Lalu kompos ditutup menggunakan terpal selama 3 minggu dan dilakukan pembalikan dua hari sekali. Kompos yang telah matang tidak mengeluarkan aroma atau bau busuk dan berwarna lebih gelap (coklat kehitaman). 


\section{Penanaman}

Benih cabai Hiyung direndam selama 30 menit untuk mengetahui benih bagus atau tidak. Benih yang mengapung dibuang. Benih yang tenggelam dikeringkan lalu disemai dalam polybag semai dengan media tanah dan pupuk kandang, selama 3 minggu (sampai ada 3-4 daun).

Pengolahan lahan dilakukan dengan membuat 20 bedengan yang masing-masingnya berukuran $1,5 \mathrm{~m} \times 2 \mathrm{~m}$. Jarak tanam $50 \mathrm{~cm} \times 50 \mathrm{~cm}$ dengan 12 bibit dalam satu bedengan. Jarak tiap-tiap bedengan $50 \mathrm{~cm}$ dan tinggi bedengan dibuat $20 \mathrm{~cm}$. Pemupukan dilakukan setelah lahan selesai diolah, dengan pemberian pupuk kompos sesuai perlakuan dengan cara di masukan ke dalam lubang tanam dan didiamkan selama satu minggu.

Bibit cabai rawit Hiyung ditanam dengan mengisi tiap lubang terdiri atas 1 bibit. Pupuk NPK mutiara 16:16:16 diberikan sebagai pupuk dasar bukan perlakuan; dengan dosis $300 \mathrm{~kg}$ per ha setara 7,5 g per lubang tanaman, setelah tanaman dipindah dengan membuet alur lingkaran kebedengan, dengan berjarak $2 \mathrm{~cm}$ dari batang tanaman.

Pemeliharaan dilakukan dengan cara penyiraman dua kali sehari pada sore dan pagi hari, kecuali jika ada hujan. Selain itu juga dilakukan penyulaman jika tanaman mati, pengendalian dilakukan jika terdapat hama dengan mengambil hama secara langsung, serta menyiangi gulma di sela-sela tanaman.

Pengamatan dilakukan per 14, 21, 28, 35 dan 42 hari setelah tanam (HST). Variabel-variabel yang diamati berupa tinggi tanaman, diukur mulai dari ujung pangkal batang hinga sampai titik tumbuh daun, semua jumlah daun yang membuka sempurna dan jumlah cabang produktif (muncul bunga) selama 7 hari setelah cabang mengeluarkan bunga.

\section{Rancangan Percobaan dan Analisis Data}

Penelitian menggunakan Rancangan Acak Lengkap (RAL). Perlakuan berupa faktor tunggal yang mencakup 5 taraf perlakuan, yaitu $\mathrm{K}_{0}: 0$ ton per ha, $\mathrm{K}_{1}: 5$ ton per ha setara $125 \mathrm{~g}$ per lubang tanaman, $\mathrm{K}_{2}: 10$ ton per ha setara $250 \mathrm{~g}$ per lubang tanaman, $\mathrm{K}_{3}: 15$ ton per ha setara $375 \mathrm{~g}$ per lubang tanaman dan $\mathrm{K}_{4}: 20$ ton per ha setara $500 \mathrm{~g}$ per lubang tanaman. Percobaan dilakukan dengan 4 ulangan, sehingga terdapat 20 satuan percobaan. Uji kehomogenan data dilakukan dengan uji Bartlett, analisis data dengan analisis ragam (Anova), dilanjutkan dengan uji DMRT pada rtaraf 0,05 jika terdapat pengaruh perlakuanyang nyata.

\section{HASIL DAN PEMBAHASAN}

\section{Tinggi Tanaman Cabai Rawit Hiyung}

Hasil dari analisis ragam pada pengukuran tinggi tanaman cabai Hiyung dengan pengaplikasian kompos limbah baglog jamur tiram putih pada umur 14 HST, menunjukan tidak ada pengaruh nyata, namun pada umur 21, 28, 35, dan 42 HST terdapat pengaruh yang nyata (Gambar 1). Aplikasi kompos tidak memberikan pengaruh yang nyata pada 14 HST disebabkan lambatnya penyerapan unsur hara oleh tanaman, karena kompos limbah baglog jamur tiram merupakan pupuk organik padat. Menurut Hayati (2010), efek positif dari pupuk organik tidak berperan cepat, namun perlu waktu tertentu agar berpengaruh maksimal pada pertumbuhan tanaman.

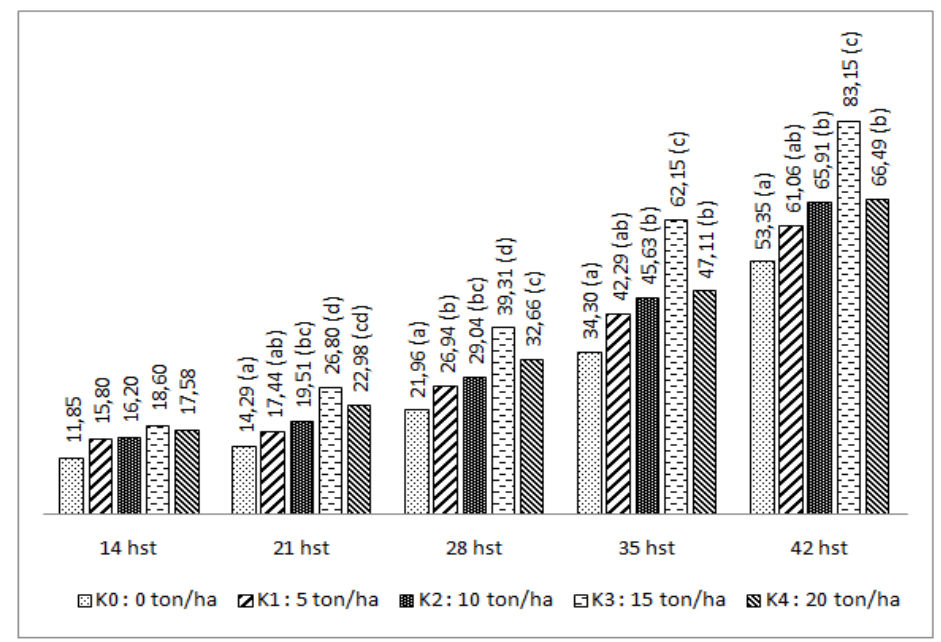

Keterangan : DMRT pada taraf nyata $5 \%$.

Gambar 1. Tinggi tanaman cabai rawit Hiyung dengan aplikasi kompos limbah baglog jamur tiram putih 
Semua taraf perlakuan memberikan pengaruh terhadap tinggi tanaman cabai rawit Hiyung, kecuali kontrol. Perlakuan kompos limbah baglog yang menghasilkan nilai rata-rata lebih tinggi adalah 15 ton per ha, dibandingkan perlakuan lainnya. Dengan demikian, pada takaran 15 ton per ha kompos limbah media baglog sudah mampu menunjang pertumbuhan tinggi tanaman cabai rawit Hiyung. Kompos limbah baglog mengandung N 2,03\%, P 0,61\% dan $\mathrm{K} 1,78 \%$, dari kandungan hara tersebut sudah mampu memenuhi kebutuhan hara bagi tanaman cabai rawit Hiyung secara optimal pada 15 ton per ha kompos. Hal ini sesuai hasil penelitian Farhan et al. (2018) bahwa pada tingkat kandungan hara yang lebih rendah, yaitu unsur $\mathrm{N} 0,92 \%, \mathrm{P} 0,17 \%$ dan $\mathrm{K} 0,25 \%$, belum mampu mencukupi kebutuhan hara cabai rawit yang menyebabkan pertumbuhan tanaman menjadi terhambat.

Jika dosis ditambahkan menjadi 20 ton per ha kompos limbah baglog, tanaman justru menunjukkan penurunan tingginya. Penurunan tinggi tanaman terjadi karena unsur hara dalam tanah berlebihan, kemudian mengganggu keseimbangan dalam tanah dan mengakibatkan tanaman tidak optimal menyerap unsur hara. Maruli et al (2012) berpendapat bahwa pengaplikasian pupuk dengan dosis yang tepat akan meningkatkan tinggi tanaman, sedangkan pengaplikasian pupuk dengan dosis yang berlebihan akan memperlambat pertumbuhan tanaman dan pengaplikasian pupuk dengan dosis yang kurang akan membuat tanaman menjadi kerdil.

Tinggi tanaman pada masa vegetatif akan berpengaruh terhadap hasil panen cabai rawit dimasa generatif. Sujitno dan Dianawati (2015) menyatakan bahwa produksi cabai rawit dipengaruhi oleh tinggi tanaman sebesar $92 \%$. Hermansyah dan Inoriah (2009) berpendapat bahwa terbentuknya tunas untuk memperbanyak jumlah cabang dipengaruhi oleh tinggi tanaman.

\section{Jumlah Daun Cabai Rawit Hiyung}

Hasil analisis ragam pada pengukuran rata-rata jumlah daun dengan pengaplikasian kompos limbah baglog jamur tiram putih pada cabai Hiyung 14, 21, 28, 35, dan 42 HST menunjukkan adanya pengaruh yang nyata (Gambar 2). Berdasarkan analisis ragam terlihat bahwa hasil pemberian kompos limbah baglog berpengaruh nyata saat umur tanaman cabai rawit Hiyung 14, 21, 28, 35 dan 42 HST. Adanya pengaruh yang nyata dari pengaplikasian kompos terjadi karena tersedianya unsur hara yang cukup bagi tanaman, sehingga kemudian mampu merangsang fotosintesis pada tanaman untuk menghasilkan daun lebih banyak. Hal ini sesuai dengan peryataan Annisava et al. (2014) bahwa lancarnya proses metabolisme tanaman berupa fotosintesis dapat mempengaruhi pertumbuhan daun yang dikontrol oleh ketersediaan unsur hara bagi tanaman.

Dibandingkan perlakuan lainnya, kerlakuan kompos limbah baglog jamur tiram putih 15 ton per ha menghasilkan rata-rata jumlah daun yang terbanyak. Hal ini disebabkan pada perlakuan tersebut tinggi tanamannya juga jauh lebih tinggi. Jumlah daun dengan tinggi tanaman saling berhubungan, semakin banyak daun yang terbentuk semakin tinggi tanaman dan sebaliknya, sesuai dengan pernyataan Ifantry dan Ardiyanto (2015) bahwa daun dapat tumbuh di setiap ruas batang tanaman, sehingga jika tanaman semakin tinggi jumlah daun akan semakin banyak.

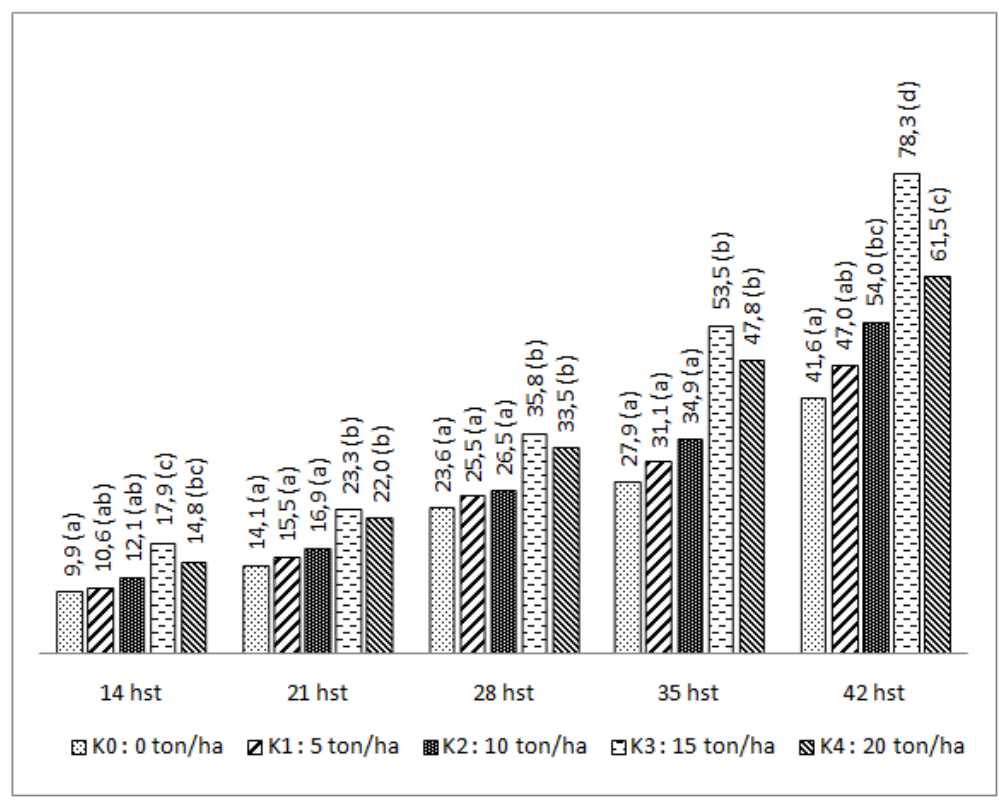

Keterangan : DMRT pada taraf nyata $5 \%$.

Gambar 2. Rata-rata jumlah helai daun cabai rawit Hiyung dengan aplikasi kompos limbah baglog jamur tiram putih 


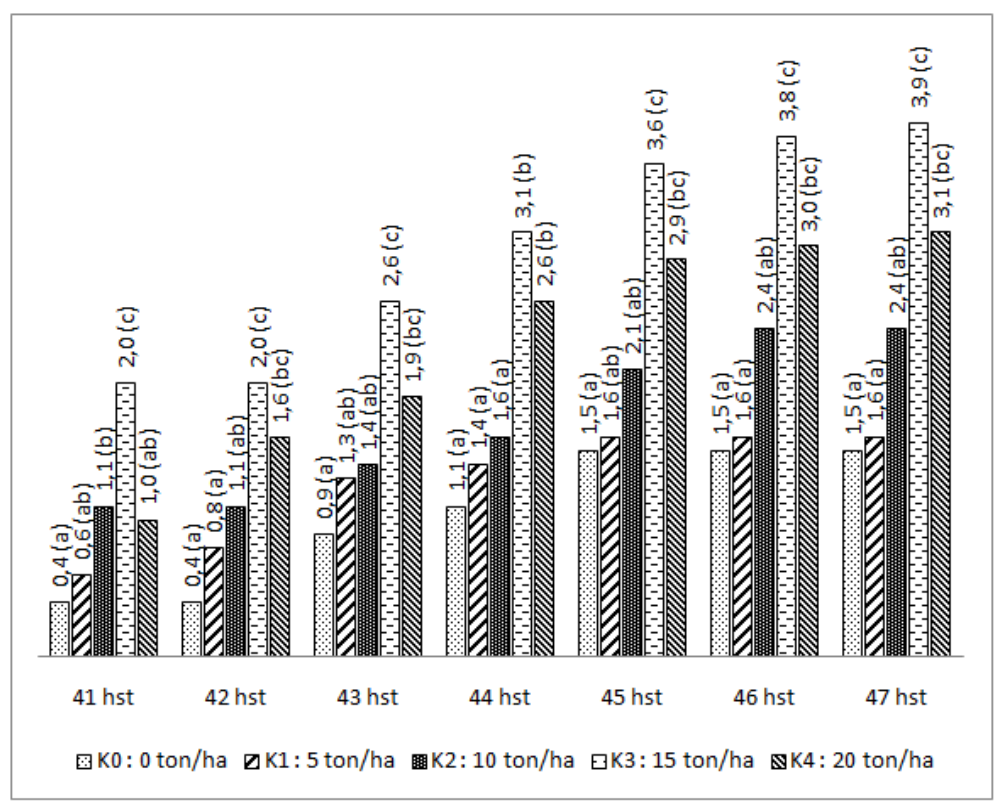

Keterangan : DMRT pada taraf nyata $5 \%$.

Gambar 3. Jumlah cabang produktif cabai rawit Hiyung dengan aplikasi kompos limbah baglog jamur tiram putih

Pemberian kompos limbah baglog sangat berpengaruh tehadap banyaknya jumlah daun cabai rawit Hiyung, yang juga dipengaruhi oleh unsur hara $\mathrm{N}$ yang berfungsi untuk berlangsungnya fotosintesis dan unsur $\mathrm{P}$ dan $\mathrm{K}$ yang dominan dalam kompos limbah baglog yang memiliki peran penting untuk pertumbuhan daun. Menurut Haryadi et al. (2015), unsur hara $\mathrm{P}$ berfungsi sebagai pembentuk gula fosfat untuk metabolisme tanaman dan membantu mengaktifkan enzimenzim dalam proses fotosintesis, sedangkan unsur hara $\mathrm{K}$ berfungsi untuk mengatur pergerakkan stomata dan dapat meningkatkan pertumbuhan jumlah daun.

Jumlah daun yang lebih banyak akan mendukung jumlah hasil panen atau berat buah per tanaman pada masa generatif, karena daun berperan sebagai tempat fotosintesis bagi tanaman dan selanjutnya untuk mendistribusikan bahan organik. Menurut (Harjadi, 1993), bila proses fotosintesis lebih besar dari respirasi maka akan meningkatkan berat kering hasil tanaman.

\section{Jumlah Cabang Produktif Cabai Rawit Hiyung}

Hasil analisis ragam pada pengukuran rata-rata cabang produktif cabai Hiyung dengan pengaplikasian kompos limbah baglog jamur tiram putih pada umur 41, 42, 42, 44, 45, 46 dan 47 HST, menunjukkan adanya pengaruh yang signifikan (Gambar 3).

Berdasarkan analisis ragam, hasil pemberian kompos limbah baglog jamur tiram putih berpengaruh pada cabang produktif saat umur tanaman 41, 42, 42, 44, 45, 46 dan 47 HST. Perlakuan kompos limbah baglog 15 ton per ha menampilkan nilai rata-rata jumlah cabang produktif yang terbanyak dibandingkan perlakuan lainnya. Hasil analisis yang berbeda nyata pada perlakuan $\mathrm{K}_{3}$ (15 ton per ha) menunjukkan percabangannya yang terlihat dua kali lipat lebih banyak dibandingkan perlakuan kontrol. Artinya pemberian kompos limbah baglog pada perlakuan $\mathrm{K}_{3}$ memberikan respon lebih efektif dalam menyerap unsur hara karena sudah cukup untuk memenuhi kebutuhan tanaman cabai rawit Hiyung. Sebagaimana dikemukakan oleh Salisbury dan Ross (1999), hukum minimum Liebig menegaskan bahwa unsur hara di bawah optimal berpengaruh untuk meningkatkan pertumbuhan, kemudian tetap maupun menurun meski dosisnya ditingkatkan.

Terlihat bahwa pada perlakuan kompos limbah baglog, banyaknya cabang produktif tanaman cabai rawit Hiyung sebanding dengan jumlah daun dan tinggi tanamannya. Menurut Rachmadhani et al. (2014) masa pertumbuhan vegetatif yang baik akan menentukan hasil tanaman dan masa generatif nya. Saat masa pembungaaan, untuk mendorong pembentukkan bunga peranan unsur hara P sangat penting. Sebagaimana Lukman (2010), P merupakan unsut hara yang akan membantu tanaman dalam pembentukan sel yang baru pada jaringan yang bermanfaat meningkatkan pertumbuhan.

Cabang sebagai tempat munculnya bunga pada tanaman sangat mempengaruhi jumlah produksi pada masa generatif, karena jumlah cabang yang banyak akan memproduksi bunga yang lebih banyak. Menurut Ganefianti et al. (2006) bahwa semakin banyak cabang semakin banyak bunga yang muncul. 


\section{KESIMPULAN}

Kesimpulan dari penelitian ini adalah bahwa aplikasi kompos limbah baglog jamur tiram putih berpengaruh terhadap tinggi tanaman, jumlah daun dan cabang produktif tanaman cabai rawit Hiyung; akan tetapi tidak berpengaruh terhadap tinggi tanaman umur 14 HST. Berdasarkan parameter pertumbuhan yang meliputi jumlah daun, cabang produktif dan tinggi tanaman cabai rawit Hiyung, perlakuan paling berbeda dengan kontrol adalah pemberian 15 ton per ha $\left(\mathrm{K}_{3}\right)$ yang meliputi tinggi tanaman 55,9\% lebih tinggi dibandingkan kontrol pada $42 \mathrm{HST}$, jumlah daun $88,2 \%$ lebih banyak dibandingkan kontrol pada 42 HST dan cabang produktif 160\% lebih banyak dibandingkan kontrol pada 42 HST.

\section{UCAPAN TERIMAKASIH}

Ucapan terima kasih disampaikan kepada Paman Uwet, pemilik budidaya jamur tiram putih, yang telah memfasilitasi penyediaan limbah baglog untuk dijadikan bahan utama kompos

\section{DAFTAR PUSTAKA}

Annisava, A.R., L. Anjela, dan B. Sofyan. 2014. Respon tanaman sawi (Brassica juncea L.) terhadap pemberian beberapa dosis bokashi sampah pasar dengan dua kali penanaman secara vertikultur. Jurnal Agroteknologi 5(1): 17-24. DOI: http://dx.doi.org/10.24014/ja.v5i1.1143.

Fadillah, M., A.J. Kirnadi, dan A. Zuraida. 2019. Tingkat kelayakan usaha cabai Hiyung (Capsicum frutescens) di beberapa luas lahan di Desa Hiyung Kecamatan Tapin Tengah Kabupaten Tapin Kalimantan Selatan. Al Ulum Sains dan Teknologi 4(2): 33-40. DOI: http://dx.doi.org/10.31602/ajst.v4i2.1977.

Farhan, Z., R. Notarianto, dan M. Kromowartomo. 2018. Pengaruh pemberian dosis pupuk organik ampas kelapa terhadap produksi tanaman cabai rawit (Capsicum frutescens L.). Jurnal Ilmiah Respati Pertanian 12(1): 770-776. DOI: https://doi.org/10.52643/jir.v9i1.82.

Ganefianti, D.W., Yulian, dan A.N. Suprapti. 2008. Korelasi dan sidik lintas antara pertumbuhan, komponen hasil dan hasil dengan gugur buah pada tanaman cabai. Akta Agrosia 9(1): 1-6.

Hamdani, U. Salawati, dan R. Nuryadin. 2016. Daya Saing Agribisnis dan Potensi Pengembangan Cabe Hiyung di Kabupaten Tapin, Kalimantan Selatan. p. 156-163. Prosiding Seminar Nasional Lahan Basah Tahun 2016, Lambung Mangkurat University Press, Banjarbaru. ISBN: 978-602-6483-33-1.

Harjadi, S.S. 1993. Pengantar Agronomi. Gramedia. Jakarta.

Haryadi, D., H. Yetti, dan S. Yoseva. 2015. Pengaruh pemberian beberapa jenis pupuk terhadap pertumbuhan dan produksi tanaman kailan (Brassica alboglabra L.). Jurnal Online Mahasiswa Fakultas Pertanian 2(2): 99-102.

Hayati, E. 2010. Pengaruh pupuk organik dan anorganik terhadap kandungan logam berat dalam tanah dan jaringan tanaman selada. Jurnal Floratek 5(2): 113-123.

Hermansyah, Y. dan E. Inoriah. 2009. Penggunaan pupuk daun dan manipulasi jumlah cabang yang ditinggalkan pada panen kedua tanaman nilam. Akta Agrosia 12(2): 194-203.

Ifantry, J. dan Ardiyanto. 2015. Pengaruh Jumlah Daun dan Jenis Pupuk Kandang terhadap Pertumbuhan dan Hasil Melon (Cucumis melo L.). Fakultas Pertanian. Universitas PGRI Yogyakarta. http://repository.upy.ac.id/124/1/cd\%20jurnal.pdf.

Koassi, C.K., R.K. Nevry, L.Y. Guilaume, Z.N. Yesse, M. Koussemon, and T.K. Kablan. 2012. Profiles of bioactive compounds of some pepper fruit (Capsicum L.) varieties grown in Cote D'ivore. Innovative Romanian Food Biotechnology 11: 23-31.

Lukman, L. 2010. Efek pemberian fosfor terhadap pertumbuhan dan status hara pada bibit manggis. Jurnal Hortikultura 20(1): 1826. DOI: http://dx.doi.org/10.21082/jhort.v20n1.2010.p\%25p.

Maruli, E. dan H. Gultom. 2012. Pengaruh pemberian NPK grower dan kompos terhadap pertumbuhan dan produksi tanaman cabai rawit (Capsicum frustescens L.). Dinamika Pertanian 27(3): 149-155.

Purnomo, R., M. Santoso dan H. Heddy. 2013. Pengaruh berbagai macam pupuk organik dan anorganik terhadap pertumbuhan dan hasil mentimun (Cucumis sativus L.). Jurnal Produksi Tanaman 1(3): 93-100.

Rachmadhani, N.W., K. Koesriharti, dan M. Santoso. 2014. Pengaruh Pupuk Organik dan Pupuk Anorganik terhadap Pertumbuhan dan Hasil Tanaman Buncis Tegak (Phaseolus vulgaris L.). Jurnal Produksi Tanaman 2(6): 443-452.

Rizki, H.B., F. Puspita. dan Adiwirman. 2015. Uji Beberapa tricho-kompos terformulasi terhadap pertumbuhan dan produksi cabai merah. Jurnal Online Mahasiswa Fakultas Pertanian 2(2): 1-14.

Roesmarkam, A. dan N.W. Yuwono. 2002. Ilmu Kesuburan Tanah. Kanisius. Yogyakarta. ISBN 979·21-0468·2.

Salisbury, F.B. and C.W. Ross. 1999. Plant Physiology. 4th edition. Brooks Cole, New York. ISBN-13: 978-0534151621.

Sujitno, E. dan M. Dianawati. 2015. Produksi panen berbagai varietas unggul baru cabai rawit (Capsicum frutescens) di lahan kering Kabupaten Garut, Jawa Barat. Prosiding Seminar Nasional Masyarakat Biodiversita Indonesia 1(4): 874-877. DOI: $10.13057 / \mathrm{psnmbi} / \mathrm{m} 010438$.

Sulaeman, D. 2011. Efek Kompos Limbah Baglog Jamur Tiram Putih (Pleurotus ostreatus Jacquin) terhadap Sifat Fisik Tanah serta Pertumbuhan Bibit Markisa Kuning (Passiflora edulis var. Flavicarpa Degner). Skripsi. Fakultas Pertanian, Institut Pertanian Bogor, Bogor. 